\title{
Thompson's hip hemiarthroplasty for neck of femur fracture: remarkable clinical outcomes at 45- year follow-up
}

\author{
Thomas Donnelly, Hosam E Matar, N Greville Farrar
}

Department of Trauma \& Orthopaedics, Leighton Hospital, Crewe, UK

\section{Correspondence to Mr Hosam E Matar, hematar@doctors.org.uk}

TD and HEM contributed equally.

Accepted 4 July 2017
CrossMark

\section{To cite: Donnelly $\mathrm{T}$,}

Matar HE, Farrar NG. BMJ Case Rep Published Online First: [please include Day Month Year]. doi:10.1136/ bcr-2017-221528

\section{Learning points}

- This report adds to the literature a new testimony of an old favourite with remarkable clinical outcomes at 45-year follow-up.

- Thompson's hip hemiarthroplasty remains an old favourite to many surgeons as it has been tried and tested over the years with ease of use and well-established clinical outcomes.

- Acetabular erosion from hemiarthroplasties can lead to pain and may require revision into total hip; however, its prevalence remains largely unknown.

\section{DESCRIPTION}

We present very interesting X-ray images of a 96-year-old woman with previous neck of femur fracture treated with Thompson's hip hemiarthroplasty 45 years ago with excellent clinical outcomes, making it one of the longest reported follow-up in the literature. She had a recent fall and presented to emergency department with difficulty weight bearing. Her clinical examination revealed symmetrical passive hip range of movements with tenderness in the pubic region. Her medical history included hypertension and left hip neck of femur fracture 45 years ago. She lives alone, fully independent with activities and mobilises independently unaided. Anteroposterior pelvic radiographs (figures 1 and 2) demonstrate left superior and inferior pubic rami fractures with well-fixed left

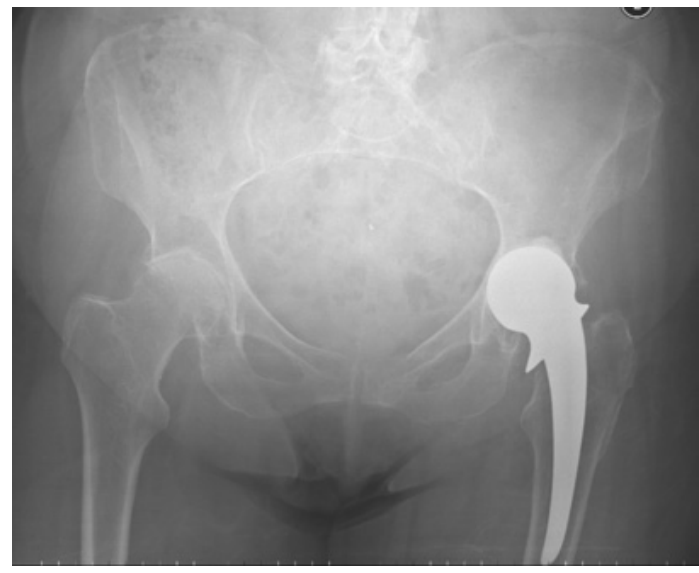

Figure 1 Anteroposterior pelvis radiograph with left hip Thompson's hemiarthroplasty and left pubic rami fractures.

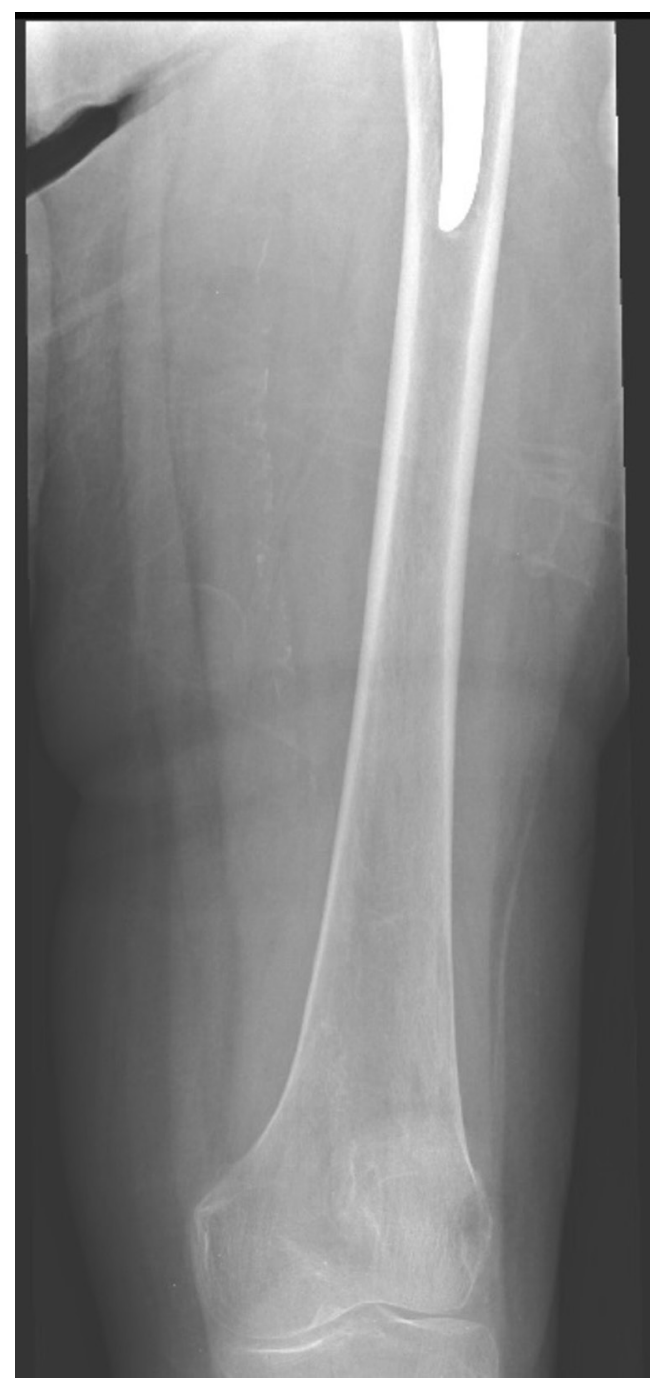

Figure 2 Plain radiograph of the distal tip of the prosthesis.

hip Thompson's hemiarthroplasty in situ with mild acetabular erosion and no evidence of loosening. She was treated conservatively with analgesia and physiotherapy and discharged into rehabilitation placement uneventfully.

Her retrospective (preinjury) Western Ontario McMaster Universities Osteoarthritis Index Score was 81.5 (maximum 100, higher score better function), Oxford Hip Score was 36 (maximum 48, higher score better function) and Harris Hip Score was 79.8 (maximum 100, higher score better function). These scores validate somewhat that she 
managed to maintain reasonable hip function and mobility into her 10th decade and the implant's 5th decade.

One of the main limitations of hemiarthroplasties is erosion of acetabular cartilage by the prosthesis. ${ }^{1}$ When erosion develops, it is likely to be accompanied by radiological signs of acetabular erosion and medial migration of the prosthesis with pain in the groin. Conversion to total hip replacement may then be necessary in active patients. However, the true prevalence, severity and clinical importance of acetabular erosion secondary to hemiarthroplasty of the hip are largely unknown. ${ }^{23}$

Contributors TD and HEM managed the patient and wrote the manuscript. GNF is the responsible consultant, managed the patient and reviewed the manuscript.

Competing interests None declared.
Patient consent Obtained.

Provenance and peer review Not commissioned; externally peer reviewed.

(C) BMJ Publishing Group Ltd (unless otherwise stated in the text of the article). All rights reserved. No commercial use is permitted unless otherwise expressly granted.

\section{REFERENCES}

1 Kassam AA, Griffiths S, Higgins G. Historical implant or current best standard? Minimum five year follow-up outcomes of cemented Thompson hemiarthroplasties. J Arthroplasty 2014;29:1745-8.

2 Parker MJ. Cemented Thompson hemiarthroplasty versus cemented Exeter Trauma stem (ETS) hemiarthroplasty for intracapsular hip fractures: a randomised trial of 200 patients. Injury 2012;43:807-10.

3 Abram SG, Murray JB. Outcomes of 807 Thompson hip hemiarthroplasty procedures and the effect of surgical approach on dislocation rates. Injury 2015;46:1013-7.

Copyright 2017 BMJ Publishing Group. All rights reserved. For permission to reuse any of this content visit

http://group.bmj.com/group/rights-licensing/permissions.

BMJ Case Report Fellows may re-use this article for personal use and teaching without any further permission.

Become a Fellow of BMJ Case Reports today and you can:

- Submit as many cases as you like

Enjoy fast sympathetic peer review and rapid publication of accepted articles

- Access all the published articles

Re-use any of the published material for personal use and teaching without further permission

For information on Institutional Fellowships contact consortiasales@bmjgroup.com

Visit casereports.bmj.com for more articles like this and to become a Fellow 